\title{
ANALISIS PENERAPAN AKUNTANSI PEMBIAYAAN IJARAH BERDASARKAN PSAK NOMOR 107 PADA PT BANK RAKYAT INDONESIA SYARIAH CABANG LHOKSEUMAWE
}

\author{
Falahuddin $^{1}$, Icut Aprilia ${ }^{2}$ \\ ${ }^{1,2}$ Prodi Akuntansi Fakultas Ekonomi dan Bisnis Universitas Malikussaleh Lhokseumawe \\ falahuddin@unimal.ac.id
}

\begin{abstract}
This study aims to analyze the application of Ijarah financing accounting based on PSAK No.107 at PT Bank Rakyat Indonesia Syariah, Branch of Lhokseumawe. The data used in this study are qualitative data which is obtained by conducting interviews with the parties concerned. The data analysis method used in this study is a qualitative descriptive method. Based on the results of the study, it is known that the financing system of Ijarah Muntahiyya Bittamlik at PT Bank Rakyat Indonesia Syariah, Branch of Lhokseumawe is in accordance with the generally accepted accounting principles for sharia banking, namely PSAK 107 concerning the application of Ijarah financing.
\end{abstract}

Keywords: Bank Rakyat Indonesia Syariah, PSAK 107, Ijarah Financing.

\section{PENDAHULUAN}

Bank syariah adalah bank yang melaksanakan kegiatan usaha berdasarkan prinsip syariah, berbeda dengan bank konvensional pada umumnya. Perbedaan utamanya terletak pada landasan operasi yang digunakan. Bank konvensional beroperasi berlandaskan bunga, sedangkan bank syariah beroperasi berlandaskan bagi hasil, jual beli, dan sewa. Apabila dilihat dari perspektif ekonomi, bank syariah dapat pula didefinisikan sebagai sebuah lembaga intermediasi yang mengalirkan investasi publik secara optimal (dengan kewajiban zakat dan larangan riba) yang bersifat produktif (dengan larangan judi) serta dijalankan sesuai nilai, etika, moral, dan prisip Islam.

Di Indonesia, bank syariah telah muncul sejak awal 1990-an dengan berdirinya Bank Muamalat Indonesia. Secara perlahan Bank Syariah mampu memenuhi kebutuhan masyarakat yang menghendaki layanan jasa perbankan yang sesuai dengan prinsip Syariah agama Islam. PT Bank Rakyat Indonesia (BRI) Syariah merupakan salah satu bank syariah yang mampu memenuhi kebutuhan masyarakat yang menghendaki layanan jasa perbankan yang sesuai dengan prinsip syariah agama Islam. PT Bank Rakyat
Indonesia (BRI) Syariah Cabang Lhokseumawe merupakan bank syariah yang didirikan di wilayah Kota Lhokseumawe, sebagaimana bank syariah pada umumnya yang berorientasi dalam upaya peningkatan kesejahteraan anggota dan masyarakat.

Ada beberapa jenis pembiayaan yang dilakukan oleh PT Bank Rakyat Indonesia Syariah Cabang Lhokseumawe, diantaranya pembiayaan Murabahah, Mudharabah, Musyarakah, dan Ijarah Muntahiyya Bittamlik.

Sri Nurhayati dan Wasilah (2009) menyatakan bahwa murabahah adalah transaksi penjualan barang dengan menyatakan harga perolehan keuntungan (margin) yang disepakati oleh penjual dan pembeli. Pembayaran atas akad beli dapat dilakukan secara tunai (ba'i naqdan) atau tangguh (ba'i mu'ajjal/ba'i bi'tsaman ajil). Sri Nurhayati dan Wasilah (2009) menyatakan bahwa murabahah adalah transaksi penjualan barang dengan menyatakan harga perolehan keuntungan (margin) yang disepakati oleh penjual dan pembeli. Pembayaran atas akad beli dapat dilakukan secara tunai (ba'i naqdan) atau tangguh (ba'i mu'ajjal/ba'i bi'tsaman ajil). 
Mudharabah adalah akad kerja sama usaha antara pemilik dana dan pengelola dana untuk kegiatan usaha, laba dibagi atas dasar nisbah bagi hasil menurut kesepakatan kedua belah pihak, sedangkan bila terjadi kerugian akan di tanggung oleh si pemilik dana kecuali disebabkan oleh misconduct, negligence atau violation oleh pengelola dana.

Musyarakah adalah akad kerja sama antara dua pihak atau lebih untuk suatu usaha tertentu, dimana masing-masing pihak memberikan konstribusi dana dengan ketentuan bahwa keuntungan dibagi berdasarkan porsi konstribusi dana.

Ijarah adalah akad pengalihan hak penggunaan atas suatu barang (manfaat) untuk jangka waktu tertentu dengan kompensasi pembayaran uang sewa tanpa diikuti oleh perubahan kepemilikan atas barang tertentu. Sedangkan ijarah muntahiyya bittamlik adalah akad sewa menyewa antara pemilik objek sewa dan penyewa untuk mendapatkan imbalan atas objek sewa yang disewakannya dengan opsi perpindahan hak milik objek sewa pada saat tertentu sesuai dengan akad sewa. (Ikatan Akuntan Indonesia: 2009).

Ijarah (sewa jasa) telah ada dari masa RasulullahSAW dan berlandaskan pada Al-Quran surah At-talaq ayat 6 : "Tempatkanlah mereka (para isteri) dimana kamu bertempat tinggal menurut kemampuanmu dan janganlah kamu menyusahkan mereka untuk menyempitkan (hati) mereka. Dan jika mereka (istri-istri yang sudah ditalaq) itu sedang hamil, maka berikanlah kepada mereka nafkahnya hingga mereka bersalin, kemudian jika mereka menyusukan (anak-anak)mu untukmu maka berikanlah kepada mereka upahnya, dan musyawarahkanlah diantara kamu (segala sesuatu) dengan baik; dan jika kamu menemui kesulitan maka perempuan lain boleh menyusukan (anak itu) untuknya.

Tujuan pembiayaan ijarah muntahiyya bittamlik yaitu suatu solusi pembiayaan islami bagi orangorang yang membutuhkan suatu barang namun tidak memiliki cukup biaya untuk angsurannya sehingga perbankan berkonstribusi dalam menyediakan fasilitas pembiayaan guna mengembangkan potensi ekonomi anggota atau masyarakat. Sebagaimana dijelaskan diatas bahwa ijarah muntahiyya bittamlik merupakan pengembangan untuk mengakomodasi kebutuhan pasar. Jadi dengan adanya ijarah muntahiyya bittamlik, perbankan sangat berperan penting dalam menyediakan fasilitas pembiayaan untuk masyarakat.

Namun demikian, Pada PT Bank BRISyariah Cabang Lhokseumawe sendiri, pembiayaan ijarah muntahiyya bittamlik masih relatif kecil, hal ini dikarenakan pembiayaan ini cenderung memiliki potensi yang merugikan salah satu pihak. Bank memiliki kemungkinan kerugian yang lebih besar daripada konsumen. Misalkan harga sewa akan cenderung mengalami peningkatan seiring dengan berjalannya waktu. Namun, harga sewa dalam akad ijarah muntahiyya bittamlik ini sudah disepakati secara tetap di awal transaksi. Berikut ini komposisi pembiayaan pada PT Bank BRISyariah Cabang Lhokseumawe pada tahun 2018.

Tabel 1

Porsi Pembiayaan Pada PT Bank BRISyariah Cabang Lhokseumawe(2018)

\begin{tabular}{|l|l|}
\hline Pembiayaan & Jumlah Nasabah \\
\hline Mudharabah & 43 \\
\hline Murabahah & 1100 \\
\hline Musyarakah & 22 \\
\hline Ijarah muntahiyya bittamlik & 21 \\
\hline Sumber: PT Bank BRISyariah Cabang
\end{tabular}

Lhokseumawe (2018)

Berdasarkan tabel 1 dapat dilihat bahwa nasabah pembiayaan ijarah masih kecil dibanding pembiayaan lainnya. Padahal dalam rangka diversifikasi produk pembiayaan, akad ini dipandang perlu untuk dioptimalkan implementasinya. Pada dasarnya akad ini bisa memberikan keuntungan baik bagi bank syariah ataupun nasabah.

Dari sejak awal perkembangan perbankan syariah di Indonesia, dari sisi pembiayaan, akad murabahah yang lebih mendominasi pembiayaan tersebut dibandingkan lainnya. Seharusnya, pembiayaan dengan akad ijarah harus lebih banyak peminatnya. Dikarenakan pada dasarnya akad ini bisa memberikan keuntungan baik bagi bank syariah ataupun nasabah. Keuntungan yang diperoleh nasabah misalnya ialah penambahan modal untuk meningkatkan investasi, sedangkan keuntungan bagi bank syariah, selain sebagai wujud diversifikasi 
produk, akad ini dapat mempercepat penyaluran dana dan meningkatkan pola investasi yang baik.

Kejadian yang serupa juga menjadi fenomena peneliti terdahulu yaitu Mila Sartika dan Hendri Hermawan Adinugraha (2016) yang menyatakan bahwa Implementasi Ijarah dan Ijarah Muntahiyya Bittamlik Pada Bank BRISyariah Cabang Yogyakarta yang menunjukkan bahwa pada realitanya ijarah dan/atau ijarah muntahiyya bittamlik ini jarang di aplikasikan oleh bank syariah bila dibandingkan dengan pembiayaan lainnya seperti pembiayaan murabahah.

Meskipun pembiayaan ijarah relatif kecil dibandingkan pembiayaan yang lain, pembiayaan ijarah juga termasuk salah satu pembiayaan yang diatur dalam Bank Umum Syariah sehingga memiliki Standar Akuntansi Syariah (SAS) dalam mengatur pengakuan, pengukuran, penyajian, dan pengungkapan transaksi ijarah. Transaksi ijarah ini diatur dalam PSAK No. 107. Perlakuan akuntansi untuk ijarah dilihat dari dua sisi pelaku yaitu pemberi sewa/mu'jir (bank) dan penyewa/musta'jir (nasabah). Bank adalah pihak yang menyediakan fasilitas pembiayaan ijarah muntahiyya bittamlik dengan cara menyewakan obyek sewa yang dimiliki bank kepada nasabah dan nasabah adalah sebagai pihak yang menerima fasilitas pembiayaan ijarah muntahiyya bittamlik dari bank yaitu penyewa atas obyek sewa yang dimiliki bank. Dalam hal ini bank dan nasabah akan melaksanakan transaksi sewa menyewa sesuai dengan ketentuan syariah atau bank akan menjual barang kepada nasabah dan nasabah akan membeli barang tersebut dari bank serta membayar harganya kepada bank. Pembiayaan ijarah meliputi aset berwujud dan aset tidak berwujud yang diperkenankan syariah.

\section{TINJAUAN PUSTAKA}

\section{Pengertian Akuntansi Syariah}

Akuntansi syariah dapat dijelaskan berdasarkan dua kosa kata, yaitu Akuntansi dan Syariah. Akuntansi adalah indentifikasi transaksi yang kemudian diikuti dengan kegiatan pencatatan, penggolongan serta pengihtisaran transaksi tersebut sehingga menghasilkan laporan keuangan yang dapat digunakan untuk pengambilan keputusan. Sedangkan Syariah adalah aturan yang telah ditetapakan oleh
Allah SWT untuk dipatuhi oleh manusia dalam menjalani segala aktivitas hidupnya di dunia.

Menurut Sri Nurhayati dan Wasilah (2009) menyatakan bahwa definisi bebas dari akuntansi adalah identifikasi transaksi yang kemudian diikuti dengan kegiatan pencatatan, penggolongan, serta pengikhtisaran transaksi tersebut sehingga menghasilkan laporan keuangan yang dapat digunakan untuk pengambilan keputusan. Sedangkan definisi bebas dari syariah adalah aturan yang telah ditetapkan oleh Allah SWT untuk dipatuhi oleh manusia dalam menjalani segala aktivitas hidupnya di dunia. Jadi, Akuntansi syari'ah ini dapat diartikan sebagai proses akuntansi atas transaksi-transaksi yang sesuai dengan aturan yang telah ditetapkan Allah SWT.

Tujuan dari akuntansi dalam Islam adalah sebagai bentuk pertanggung jawaban dan menegakkan keadilan dan kebenaran. Manfaatnya tentu sangat besar, yakni menjaga transaksi yang tercatat tersebut terekam dengan baik sehingga dikemudian hari dapat dilihat kembali dan dimanfaatkan informasinya, terutama pada transaksi-transaksi keuangan yang bersifat hutang-piutang, bahkan Allah SWT menekankan pencatatan hutang-piutang, sebagaimana termaktub dalam Al Qur'an Surah Al Baqarah ayat 282.

Niken (2003) menyatakan bahwa tujuan lain dari Bank Syariah adalah untuk memelihara dan mengembangkan jasa serta produk-produk perbankan yang sesuai dengan syariah Islam. Ciri-ciri yang melekat dari syariah adalah mengendalikan etika sehingga dapat terjaga integritasnya dalam menciptakan rasa keadilan bagi semua masyarakat. Bank syariah dapat menghasilkan keuntungan dalam operasionalnya. Jika tidak, bank syariah tersebut dapat disebut tidak amanah dalam mengelola dana yang di invetasikan masyarakat. Bank syariah memiliki tujuan yang lebih luas dibandingkan bank konvensional.

\section{Bank Syariah}

Setyorini (2003) menyatakan bahwa bank merupakan lembaga keuangan yang memiliki tujuan utama yaitu badan usaha yang menghimpun dana dari masyarakat dan menyalurkan dana kepada masyarakat dalam bentuk pinjaman atau kredit dalam rangkameningkatkan taraf hidup rakyat banyak. Pada umumnya, masyarakat relatif paham tentang fungsi 
serta fasilitas yang dapat diperolehnya atau disediakaan oleh bank umum untuk memenuhi kebutuhan masyarakat banyak. Selain menyalurkan fasilitas pinjaman atau kredit kepada masyarakat, bank juga menyediakan fasilitas yang memungkinkan untuk masyarakat menyimpan investasi atau dana kepada pihak bank.

Verra (2012) menyatakan bahwa pada dasarnya bank syariah mengimplementasikan konsep yang sangat berbeda dengan bank konvensional. Produknya pun juga berbeda antara bank konvensional dengan bank syariah. bahkan produk yang merupakan bisnis utama, pencetak pendapatan terbesar bagi sebuah bank konvensional misalnya, yaitu fasilitas kredit dengan sistem bunga (riba) yang melekat pada bank konvensional, justru merupakan hal yang amat dilarang oleh bank syariah. Secara garis besar bank syariah dan bank konvensional sama dalam bentuk sistem, penarikannya, selain itu sebagai lembaga yang membutuhkan dana baik untuk keperluan produktif maupun konsumtif. Namun bank konvensional dan bank syariah terdapat perbedaan yang berkaitan dengan aspek legal, struktur organisasi usaha-usaha yang dibiayai.

Muhammad (2005) menyatakan bahwa Bank Islam atau selanjutnya disebut dengan Bank Syariah adalah bank yang beroperasi dengan tidak mengenalkan pada bunga. Bank islam atau biasa disebut dengan bank tanpa bunga adalah lembaga keuangan/perbankan yang operasionalnya dan produknya dikembangkan berlandaskan Al-Quran dan Hadist atau dengan kata lain Bank Islam adalah lembaga keuangan yang usaha pokoknya memberikan pembiayaan dan jasa-jasa lainnya dalam lalu lintas pembayaran serta peredaran uang yang pengoperasiannya disesuaikan dengan prinsip syariat Islam.

Setyorini (2003) menyatakan bahwa perbankan syariah merupakan salah satu aplikasi dari sistem ekonomi Islam yang melarang pengguna sistem bunga dalam perekonomian, karena sistem tersebut termasuk riba haram yang dilarang oleh Islam. Sistem provit and loss sharing yang merupakan keunggulan bagi bank syariah antara lain pertama memungkinkan para nasabah untuk ikut mengontrol perkembangan bank, misalnya menggunakan perhitungan profit sharing yang diperoleh tiap bulan. Kedua, tidak terpengaruh atas naik turunnya tingkat suku bunga perbankan.
Hasanuddin (2004:74) menyatakan bahwa Bank Syariah adalah bank yang dapat memberikan jasa dalam lalu lintas pembayaran yang sesuai dengan syariat Islam, dimana pencatatan transaksi dan pengikhtisaran serta pelaporannya dapat memberikan suatu informasi bagi si pemakai.

Menurut Sutan Remy Shahdeiny (2007) Bank Syariah adalah lembaga yang berfungsi sebagai intermediasi yaitu mengerahkan dana dari masyarakat dan menyalurkan kembali dana-dana tersebut kepada masyarakat yang membutuhkan dalam bentuk pembiayaan tanpa berdasarkan prinsip bunga, melainkan berdasarkan prinsip syariah.

Muhammad (2000:13) menyatakan bahwa Bank Syariah adalah lembaga keuangan yang usaha pokoknya memberikan pembiayaan dan jasa jasa lainnya dalam lalu lintas pembayaran serta peredaran uang yang pengoperasiannya disesuaikan dengan prinsip Syariat Islam.

Yumanita (2005:4) mengemukakan bahwa :

"Bank Syariah adalahlembaga intermediasi dan penyedia jasa keuangan yang bekerja berdasarkan etika dan sistem nilai islam, khususnya yang bebas dari bunga (Riba), bebas dari kegiatan spekulatif yang non produktif seperti perjudian (Maysir), bebas dari hal-hal yang tidak jelas dan meragukan (Gharar), prinsip keadilan, dan hanya membiayai kegiatan usaha yang halal".

Berdasarkan pendapat ahli tersebut dapat disimpulkan bahwa bank syariahmerupakan lembaga intermediasi yang bekerja berdasarkan etika dan sistem nilai islam, khususnya yang bebas dari bunga (Riba), bebas dari kegiatan spekulatif yang non produktif seperti perjudian (Maysir), bebas dari halhal yang tidak jelas dan meragukan (Gharar), prinsip keadilan, dan hanya membiayai kegiatan usaha yang halal.

\section{Dasar Hukum Bank Syariah di Indonesia}

Bank syariah di tanah air mendapatkan pijakan yang kokoh setelah adanya regulasi sektor perbankan pada tahun 1983. Hal ini karena sejak saat itu diberikan keleluasaan penentuan tingkat suku bunga, termasuk nol persen ( atau peniadaan bunga). Sungguhpun demikian kesempatan ini belum termanfaatkan karena tidak diperkenankannya pembukaan kantor bank baru. Kemudian posisi bank syariah semakin pasti setelah diusahakannya Undang Undang Perbankan No. 7 tahun 1992 dimana bank 
diberikan kebebasan untuk menentukan jenis imbalan yang akan diambil dari nasabahnya baik bunga ataupun keuntungan bagi hasil.

Dengan terbitnya Peraturan Presiden No. 72 tahun 1992 tentang bagi hasil yang secara tegas memberikan batasan bahwa bank bagi hasil tidak boleh melakukan kegiatan usaha yang tidak berdasarkan prinsip bagi hasil ( bunga ) sebaliknya pula bank yang kegiatan usahanya tidak berdasarkan prinsip bagi hasil tidak diperkenankan melakukan kegiatan usaha berdasarkan prinsip bagi hasil. Dikeluarkannya Undang Undang ini, maka operasional perbankan syariah semakin luas.

Titik kulminasi telah tercapai dengan disahkannya Undang Undang No. 10 tahun 1998 tentang perbankan yang membuka kesempatan bagi siapa saja yang akan mendirikan bank syariah maupun yang ingin mengkonversi dari sistem konvensional ke sistem syariah. Undang Undang ini juga melakukan revisi beberapa pasal yang dianggap pentingdan merupakan aturan hukum secara leluasa menggunakan istilah syariah dengan tidak lagi menggunakan istilah bagi hasil.

Untuk menjalankan Undang Undang tersebut selanjutnya dikeluarkan Surat Keputusan Direksi Bank Indonesia tentang Bank Umum dan Bank Perkreditan Rakyat tahun 1999 dilengkapi Bank berdasarkan prinsip syariah. Aturan yang berkaitan dengan bank umum berdasarkan prinsip syariah diatur dalam Surat Keputusan Direksi Bank Indonesia No. 32/34/KEP/DIR tanggal 12 Mei 1999.Dasar-dasar hukum positif inilah yang dijadikan pijakan bagi bank syariah Indonesia dalam mengembangkan produk-produknya dan operasionalnya.

\section{Landasan Syariah dan Fatwa DSN Ijarah}

1. Al-Quran

"Tempatkanlah mereka (para isteri) di mana kamu bertempat tinggal menurut kemampuanmu dan janganlah kamu menyusahkan mereka untuk menyempitkan (hati) mereka. dan jika mereka (isteri-isteri yang sudah ditalaq) itu sedang hamil, Maka berikanlah kepada mereka nafkahnya hingga mereka bersalin, kemudian jika mereka menyusui (anak-anak)mu untukmu Maka berikanlah kepada mereka upahnya, dan musyawarahkanlah di antara kamu (segala sesuatu) dengan baik; dan jika kamu menemui kesulitan Maka perempuan lain boleh menyusukan (anak itu) untuknya." (QS. Ath-Thalaq: 6) "Salah seorang dari kedua wanita itu berkata: "Ya bapakku ambillah ia sebagai orang yang bekerja (pada kita), karena Sesungguhnya orang yang paling baik yang kamu ambil untuk bekerja (pada kita) ialah orang yang kuat lagi dapat dipercaya." (QS. Qashash: 26)

2. Al-Hadist

"Berikanlah upah pekerja sebelum keringatnya kering”. (HR.Ibn Majah dari Ibnu Umar) "Barang siapa mempekerjakan pekerja, beritahukan-lah upahnya”. (HR. Abd ar-Razzaq dari Abu Hurairah dan Abu Sa'id al Khuduri) "Dahulu kita menyewa tanah dengan jalan membayar dengan hasil tanaman yang tumbuh disana. Rasulullahlalu melarang cara yang demikian dan memerintahkan kami agar membayarnya dengan uang mas atau perak." (HR. Ahmad, Abu Daud, dan Nasaiy dari Sa'd bin Abi Waqas)

3. Ijma'

Mengenai disyariatkannya ijarah, semua Ulama bersepakat, tidak ada seorang ulama pun yang membantah kesepakatan ijma' ini, sekalipun ada beberapa orang diantara mereka yang berbeda pendapat dalam tataran teknisnya.Pakar-pakar keilmuan dan cendekiawan sepanjang sejarah di seluruh negeri telah sepakat akan legitimasi ijarah. Dari beberapa nash yang ada, kiranya dapat dipahami bahwa ijarah itu disyariatkan dalam Islam, karena pada dasarnya manusia senantiasa terbentur pada keterbatasan dan kekurangan. Oleh karena itu, manusia antara yang satu dengan yang lain selalu terikat dan saling membutuhkan. Ijarah (sewa menyewa) merupakan salah satu aplikasi keterbatasan yang dibutuhkan manusia dalam kehidupan bermasyarakat.Bila dilihat uraian diatas, rasanya mustahil manusia bisa berkecukupan hidup tanpa berijarah dengan manusia.Oleh karena itu boleh dikatakan bahwa pada dasarnya ijarah itu adalah salah satu bentuk aktivitas antara dua pihak atau saling meringankan, serta termasuk salah 
satu bentuk tolong menolong yang diajarkan agama.

4. Fatwa DSN 09/DSN-MUI/IV/2000 Tentang Pembiayaan Ijarah Ketentuan objek ijarah dan kewajiban Lembaga Keuangan Syariah dan nasabah dalam pembiayaan ijarah di dalam Fatwa Dewan Syariah Nasional No. 9/DSN-MUI/2000, tentang pembiayaan ijarah, yaitu :

a. Rukun dan Syarat Ijarah :

1. Sighat Ijarah, yaitu ijab dan qabul berupa pernyataan dari kedua belah pihak yang berakad (berkontrak), baik secara verbal atau dalam bentuk lain.

2. Pihak-pihak yang berakad: terdiri atas pemberi sewa/pemberi jasa dan penyewa/pengguna jasa.

3. Objek akad ijarah yaitu :

a) Manfaat barang dan sewa, atau

b) Manfaat jasa atau upah

Kedua: Ketentuan Objek Ijarah:

1. Objek ijarah adalah manfaat dari penggunaan barang dan atau jasa.

2. Manfaat barang atau jasa harus bisa dinilai dan dapat dilaksanakan dalam kontrak.

3. Manfaat barang atau jasa harus bersifat dibolehkan (tidak diharamkan).

4. Kesanggupan memenuhi manfaat harus nyata dan sesuai dengan syariah.

5. Manfaat barang atau jasa harus dikenali secara spesifik sedemikian rupa untuk menghilangkan jahalah (ketidakjelasan) yang akan mengakibatkan sengketa.

6. Spesifikasi manfaat harus dinyatakan dengan jelas, termasuk jangka waktunya. Bisa juga dikenali dengan spesifikasi atau identifikasi fisik.

7. Sewa atau upah harus disepakati dalam akad dan wajib dibayar oleh penyewa/pengguna jasa kepada pemberi sewa/pemberi jasa (LKS) sebagai pembayaran manfaat atau jasa. Sesuatu yang dapatdijadikan harga (tsaman) dalam jual beli dapat pula dijadikan sewa atau upah dalam ijarah.

8. Pembayaran sewa atau upah boleh berbentuk jasa (manfaat lain) dari jenis yang sama dengan objek kontrak.

9. Kelenturan (flexibility) dalam menentukan sewa atau upah dapat diwujudkan dalam ukuran waktu, tempat dan jarak.

Ketiga: Kewajiban LKS dan Nasabah dalam Pembiayaan Ijarah

1. Kewajiban LKS sebagai pemberi manfaat barang atau jasa :

a. Menyediakan barang yang disewakan atau jasa yang diberikan.

b. Menanggung biaya pemeliharaan barang.

c. Menjamin bila terdapat cacat pada barang yang disewakan.

2. Kewajiban nasabah sebagai penerima manfaat barang atau jasa :

a. Membayar sewa atau upah dan bertanggung jawab untuk menjaga keutuhan barang serta menggunakannya sesuai akad (kontrak).

b. Menanggung biaya pemeliharaan barang yang sifatnya ringan (tidak materiil).

c. Jika barang yang dirusak. Bukan karena pelanggaran dari penggunaan yang dibolehkan, juga bukan karena kelalaian pihak penerima manfaat dalam menjaganya, ia tidak bertanggung jawab atas kerusakan tersebut.

Keempat:

Jika salah satu pihak tidak menunaikan kewajibannya atau jika terjadi perselisihan diantara para pihak, maka penyelesaiannya dilakukan melalui Badan Arbitrase Syariah setelah tidak tercapai kesepakatan melalui musyawarah

\section{Karakteristik Bank Syariah}


Kegiatan bank syariah merupakan implementasi dari prinsip ekonomi Islam dengan karakteristik sebagaimana menurut Wiyono (2005:75), yakni:

a. Pelarangan riba dalam berbagai bentuknya.

b. Tidak mengenal konsep nilai waktu dari uang (time value of money).

c. Konsep uang sebagai alat tukar bukan sebagai komoditas.

d. Tidak diperkenankan melakukan kegiatan yang bersifat spekulatif.

e. idak diperkenankan menggunakan dua harga untuk satu barang.

f. Tidak diperkenankan dua transaksi dalam satu akad.

Perlu diketahui Suatu transaksi harus sesuai dengan prinsip syariah apabila telah memenuhi syarat-syarat sebagaimana menurut Wiyono (2005:75), yakni:

a. Transaksi tidak mengandung unsur kedholiman; Bukan riba.

b. Tidak membayarkan pihak sendiri atau pihak lain.

c. Tidak ada penipuan.

d. Tidak mengandung materi-materi yang diharamkan.

e. Tidak mengandung unsur judi.

\section{Produk Bank Syariah}

Ascarya (2011:112) menyatakan bahwa produk bank syariah terbagi menjadi empat, yaitu:

\section{Produk pendanaan yang meliputi:}
a. pola titipan (wadiah),
b. pinjaman (qardh),
c. bagi hasil (mudharabah),
d. deposito dan obligasi serta sewa (ijarah).

2. Produk pembiayaan meliputi:
a. pola bagi hasil (mudharabah dan musyarakah),
b. jual beli (murabahah, salam, isthisna),
c. sewa (ijarah),
d. serta pinjaman (qardh).

3. Produk jasa perbankan yang meliputi:
a. pola titipan (wadiah),
b. bagi hasil (mudharabah),
c. dan pola lain (wakalah, kafalah, hawalah, rahn, ujr, sharf).

4. Produk kegiatan sosial dalam bentuk pola pinjaman(qardh)yang diterapkan untuk dana talangan kepada nasabah dan sumbangan sektor usaha kecil.

\section{Ijarah}

\section{Pengertian Ijarah dan Ijarah Muntahiyya Bittamlik}

Ikatan Akuntan Indonesia (1:2009) Ijarah adalah akad pemindahan hak guna (manfaat) atas suatu aset dalam waktu tertentu dengan pembayaran sewa (ujrah) tanpa diikuti dengan pemindahan kepemilikan aset itu sendiri. Sewa yang dimaksud adalah sewa operasi (operating lease). Sedangkan ijarah muntahiyya bittamlik adalah ijarah dengan wa'ad perpidahan kepemilikan aset yang di ijarahkan pada saat tertentu.

Menurut sayyid sabiq dalam fiqih sunah, Al ijarah berasal dari kata $A l$ ajru yang berarti $A l$ 'iwadhu (ganti/kompensasi).Ijarah dapat di definisikan sebagai akad pemindahan hak guna (manfaat) atas suatu barang atau jasadalam waktu tertentu dengan pembayaran upah sewa (ujrah), tanpa diikuti dengan pemindahan kepemilikan atas suatu barang atau jasa (mempekerjakan seseorang) dengan jalan penggantian (membayar sewa atau upah sejumlah tertentu).

Akad ijarah merupakan akad yang memfasilitasi transaksi pemindahan hak guna (manfaat) atas suatu barang atau jasa dalam waktu tertentu melalui pembayaran sewa/upah tanpa diikuti pemidahan kepemilikan barang. Bagi bank syariah, transaksi ini memiliki beberapa keunggulan jika dibandingkan dengan jenis akad lainnya yaitu dibandingkan dengan akad murabahah, akad ijarah lebih fleksibel dalam hal objek transaksi, dibandingkan dengan investasi, akad ijarah mengandung resiko usaha yang lebih rendah, yaitu adanya pendapatan sewa yang relatif tetap.

\section{Ketentuan Syariah Akad Ijarah}

Transaksi ijarah dalam kedua bentuknya sebagai transaksi umum akan sah apabila terpenuhi rukun dan ketentuan. Menurut Sri Nurhayati dan Wasilah (2009) rukun ijarah ada tiga macam, yaitu :

1. Pihak-pihak yang berakad: terdiri atas pemberi sewa/pemberi jasa/mu'jjir dan penyewa/pengguna jasa/musta 'jir.

2. Objek akad ijarah adalah: manfaat barang dan sewa atau manfaat jasa dan pembayaran upah. 
3. Sighat ijarah, yaitu Ijab dan qabul berupa pernyataan dari kedua belah pihak yang berakad (berkontrak).

Menurut Sri Nurhayati dan Wasilah (2009)

ketentuan syariah yaitu :

1. Pelaku; harus cakap hukum dan baligh

2. Objek ijarah adalah manfaat dari penggunaan barang dan/atau jasa

- Manfaat aset/jasa adalah sebagai berikut :

a. Harus bisa dinilai dan dapat dilaksanakan dalam kontrak, misalnya sewa komputer, maka komputer itu harus dapat berfungsi sebagaimana mestinya, dan tidak rusak.

b. Harus yang bersifat dibolehkan secara syariah (tidak diharamkan); maka ijarah atas objek sewa melanggar perintah Allah tidak sah. Misalnya mengupah seseorang untuk membunuh, menyewakan rumah untuk tempat main judi atau menjual khamar dan lain sebagainya

c. Dapat dialihkan secara syariah, contoh manfaat yang tidak dapat di alihkan secara syariah sehingga tidak sah akadnya

d. Harus dikenali secara spesifik sedemikian rupa untuk menghilangkan ketidaktahuan yang dapat menimbulkan sengketa, misalnya kondisi fisik mobil yang disewa. Untuk mengetahui kejelasan manfaat dari suatu aset dapat dilakukan identifikasi fisik.

e. Jangka waktu penggunaan manfaat ditentukan dengan jelas

f. LKS sebagai pembayaran manfaat. Sesuatu yang dapat dijadikan harga dalam jual beli dapat pula dijadikan sewa atau upah dalam ijarah.

g. Pembayaran sewa atau upah boleh berbentuk jasa (manfaat lain) dari jenis yang sama dengan obyek kontrak.

h. Kelenturan (flexibility) dalam menentukan sewa atau upah dapat diwujudkan dalam ukuran waktu, tempat, dan jarak.

i. Jenis/barang yang dapat disewakan: Barang modal: aset tetap, misalnya bangunan, gedung, kantor, ruko dll. Barang produksi: mesin, alat-alat berat dll. Barang kendaraan transportasi: darat, laut, dan udara. Jasa untuk membayar ongkos: uang sekolah/kuliah, tenaga kerja, hotel, angkutan, dan transportasi

- Ketentuan syariah untuk ijarah muntahiyya bit tamlik a. Pihak yang melakukan ijarah muntahiyya bittamlik harus melaksanakan akad ijarah terlebih dahulu. Akad pemindahan kepemilikan, baik dengan jual beli ataupun pemberian/hibah, hanya dapat dilakukan setelah berakhirnya akad ijarah.

b. Janji pemindahan kepemilikan yang disepakati di awal akad ijarah adalah wa'ad, yang hukumnya tidak mengikat. Apabila janji itu dilaksanakan, maka harus ada akad pemindahan kepemilikan yang dilakukan setelah berakhirnya akad ijarah.

3. Ijab kabul adalah pernyataan dan ekspresi saling rida/rela di antara pihak-pihak pelaku akad dilakukan secara verbal, tertulis, melalui korespondensi atau menggunakan cara-cara komunikasi modern.

\section{Jenis-jenis Ijarah}

Menurut PSAK Nomor 107, ijarah dibagi menjadi:

1. Ijarah merupakan sewa menyewa objek ijarah tanpa perpindahan resiko dan manfaat yang terkait kepemilikan aset terkait, dengan atau tanpa wa'ad (janji) untuk memindahkan kepemilikan dari pemilik (mu'jir) kepada penyewa (musta'jir) pada saat tertentu.

2. Ijarah muntahiyya bittamlik adalah ijarah dengan wa'ad perpindahan kepemilikan aset yang diijarahkan pada saat tertentu. Perpindahan kepemilikan suatu aset yang disewakan dari pemilik kepada penyewa, dalam ijarah muntahiyya bittamlik dapat dilakukan jika seluruh pembayaran sewa atas objek ijarah yang dialihkan telah selesai dan objek ijarah telah diserahkan kembali kepada pemberi sewa. Kemudian untuk perpindaahan kepemilikan akan dibuat akad baru, terpisah dari akad ijarah sebelumnya.

3. Jual dan ijarah adalah transaksi menjual objek ijarah kepada pihak lain, dan kemudian menyewa kembali objek ijarah tersebut yang ditelah dijual tersebut. Alasan dilakukannya transaksi tersebut bisa saja si pemilik aset membutuhkan uang sementara ia masih memerlukan manfaat dari aset tersebut. Transaksi jual dan ijarah harus merupakan transaksi yang terpisah dan tidak saling bergantung (ta'alluq) sehingga harga jual harus dilakukan pada nilai wajar dan penjual akan mengakui keuntungan atau kerugian atau pada 
periode terjadinya penjualan dalam laporan laba rugi. Keuntungan atau kerugian yang timbul dari transaksi jual tidak dapat diakui sebagai pengurang atau penambah beban ijarah yang muncul karena ia menjadi penyewa.

4. Ijarah-lanjut adalah suatu entitas menyewakan lebih lanjut kepada pihak lain atas aset yang sebelumnya disewa dari pemilik, maka entitas tersebut menerapkan perlakuan akuntansi pemilik dan akuntansi penyewa. Jika suatu entitas menyewa objek ijarah (sewa) untuk disewalanjutkan, maka entitas mengakui sebagai beban ijarah (sewa) tangguhan untuk pembayaran ijarah jangka panjang dan sebagai beban ijarah (sewa) untuk sewa jangka pendek. Perlakuan akuntansi penyewa diterapkan untuk transaksi antara entitas (sebagai penyewa) dengan pemilik dan perlakuan akuntansi pemilik diterapkan untuk transaksi antara entitas (sebagai pemilik) dengan pihak penyewa-lanjut.

\section{Pembatalan Ijarah}

Sri Nurhayati dan Wasilah (2009) menyatakan bahwa transaksi ijarah menjadi batal dan berakhir apabila:

1. Terjadi cacat baru pada barang sewaan di tangan musta'jir atau munculnya kembali cacat lama pada barang

2. Rusaknya barang sewaan, seperti rumah menjadi runtuh atau hewan menjadi mati

3. Rusaknya barang yang diupahkan

4. Terpenuhinya manfaat yang telah di transaksikan

5. Menurut kalangan mazhab hanafi, transaksi ijarah boleh dibatalkan secara sepihak (oleh musta'jir) karena adanya alasan yang dibenarkan

6. Tenggang waktu yang disepakati dalam akad ijarah berakhir

7. Wafatnya salah seorang yang berakad

8. Apabila ada $u d z u r$ dari salah satu pihak. Misalkan rumah yang disewakan disita negara karena terikat hutang yang banyak.

\section{Karakteristik Ijarah}

Menurut Ikatan Akuntan Indonesia (2:2009)

Adapun karakteristik ijarah adalah sebagai berikut:

1. Ijarah merupakan sewa menyewa obyek ijarah tanpaperpindahan risiko dan manfaat yang terkait kepemilikan aset terkait,dengan atau tanpa wa' ad untuk memindahkan kepemilikan daripemilik (mu’jir) kepada penyewa (musta'jir) pada saat tertentu.

2. Perpindahan kepemilikan suatu aset yang diijarahkandari pemilik kepada penyewa, dalam ijarah muntahiyahbittamlik, dilakukan jika akad ijarah telah berakhir atau diakhiridan aset ijarah telah diserahkan kepada penyewa denganmembuat akad terpisah secara:
a) hibah,
b) penjualan sebelum akhir masa akad,
c) penjualan pada akhir masa akad,
d) penjualan secara bertahap.

3. Pemilik dapat meminta penyewa untuk menyerahkanjaminan atas ijarah untuk menghindari risiko kerugian.

4. Spesifikasi obyek ijarah, misalnya jumlah, ukuran, danjenis, harus jelas diketahui dan tercantum dalam akad.

\section{Manfaat Dan Resiko Dalam Ijarah}

Menurut Antonio (2001) Manfaat dari transaksi al-ijarah untuk bank adalah keuntungan sewa dan kembalinya uang pokok. Adapun resiko yang mungkin terjadi dalam al-ijarah adalah sebagai berikut:

1. Default; nasabah tidak membayar cicilan dengan sengaja.

2. Rusak; asset ijarah rusak sehingga menyebabkan biaya pemeliharaan bertambah, terutama bila disebutkan dalam kontrak bahwa pemeliharaan harus dilakukan oleh bank.

3. Berhenti; nasabah berhenti ditengah kontrak dan tidak mau membeli asset tersebut. Akibatnya, bank harus menghitung kembali keuntungan dan mengembalikan sebagian kepada nasabah.

\section{Pengakuan Dan Pengukuran Ijarah Menurut PSAK 107}

Cakupan Standar Akuntansi Ijarah dan IMBT

Standar akuntansi tentang pembiayaan ijarah mengacu pada Peraturan Standar Akuntansi Keuangan (PSAK) No. 107 tentang Akuntansi Ijarah menggantikan PSAK No. 59 (Akuntansi Perbankan Syariah, revisi 2003). Menurut PSAK 107, Cakupan standar ini memuat tentang mekanisme transaksi dan ketentuan tentang pengakuan dan pengukuran transaksi yang terdapat dalam skema ijarah dan IMBT. Beberapa hal dicakup dalam standar ini 
adalah pengakuan dan pengukuran perolehan objek ijarah, pendapatan ijarah dan IMBT, piutang pendapatan ijarah dan IMBT, biaya perbaikan yang dikeluarkan, perpindahan hak milik objek sewa, terjadinya penurunan nilai objek sewa secara pemanen.

\section{Pengakuan Dan Pengukuran}

\section{Akuntansi Pemilik (Mu'jir)}

a. Biaya perolehan

- Objek ijarah diakui pada saat objek ijarah diperoleh sebesar biaya perolehan

- Biaya perolehan objek ijarah yang berupa aset tetap mengacu pada PSAK 16: aset tetap, dan aset tidak berwujud mengacu pada PSAK 19: aset tidak berwujud

Jurnal:

$$
\text { Dr. Aset ijarah } \quad \text { xxx }
$$

$$
\text { Kr. Kas/Utang } \quad \text { Xxx }
$$

b. Penyusutan dan Amortisasi

- Objek ijarah disusutkan atau diamortisasi, jika berupa aset yang dapat disusutkan atau di amortisasi, sesuai dengan kebijakan penyusutan atau amortisasi untuk aset sejenis selama umur manfaatnya (umur ekonomis)

- Kebijakan penyusutan atau amortisasi yang dipilih harus mencerminkan pola konsumsi yang diharapkan dari manfaat ekonomi dimasa depan obyek ijarah

- Pengaturan penyusutan obyek ijarah berupa aset tetap sesuai dengan PSAK 16: aset tetap dan amortisasi aset tidak berwujud sesuai dengan PSAK 19: aset tidak berwujud

Jurnal:

$$
\text { Dr. Biaya Penyusutan } \quad \text { xxx }
$$

$$
\text { Kr. Akm penyusutan } \quad \mathrm{xxx}
$$

c. Pendapatan dan beban

- Pendapatan sewa selama masa akad diakui pada saat manfaat atas aset telah diserahkan kepada penyewa

- Piutang pendapatan sewa diukur sebesar nilai yang dapat direalisasikan pada akhir periode pelaporan
Jurnal:

Dr. Kas/Piutang Usaha xxx Kr. Pendapatan Sewa $\quad x x x$

$>$ Jika terjadinya perbaikan obyek ijarah

Jurnal:

$$
\begin{aligned}
& \text { Dr. Biaya Perbaikan } \quad \text { xxx } \\
& \text { Kr. Kas/Utang/Perlengkapan xxx }
\end{aligned}
$$

d. Perpindahan kepemilikan

Pada saat perpindahan kepemilikan obyek ijarah dari pemilik kepada penyewa dalam ijarah muntahiyya bittamlik dengan cara:

> Hibah, maka jumlah tercatat objek ijarah diakui sebagai beban

Jurnal:

$\begin{array}{ll}\text { Dr. Beban ijarah } & \mathrm{xxx} \\ \text { Dr. Akm penyusutan } & \mathrm{xxx}\end{array}$

Kr. Aset ijarah $\quad \mathrm{xxx}$

Penjualan sebelum berakhirnya masa, sebesar sisa cicilan sewa atau jumlah yang disepakati maka selisih antara harga jual dan jumlah yang tercatat sebagai objek ijarah dapat diakui sebagai keuntungan/kerugian. Kerugian terjadi jika nilai buku lebih besar dari kas yang diterima sebaliknya jika nilai kas yang diterima lebih besar dari nilai buku maka keuntungan dapat diakui.

Jurnal:
Dr. Kas/piutang
$\mathrm{xxx}$
Dr. Akm penyusutan
$\mathrm{xxx}$
Dr. Kerugian
XXX

$\begin{array}{ll}\text { Kr. Aset ijarah } & \text { xxx } \\ \text { Kr. Keuntungan } & \text { xxx }\end{array}$

Penjualan setelah selesai masa akad, maka selisih antara harga jual dan jumlah tercatat objek ijarah diakui sebagai keuntungan atau kerugian

Jurnal:

$\begin{array}{lcc}\text { Dr. Kas/piutang } & \mathrm{xxx} & \\ \text { Dr. Akm penyusutan } & \mathrm{xxx} & \\ \text { Dr. Kerugian } & \mathrm{xxx} & \\ \quad \text { Kr. Aset ijarah } & & \mathrm{xxx} \\ \quad \text { Kr. Keuntungan } & & \mathrm{xxx}\end{array}$

Penjualan objek ijarah secara bertahap, maka selisih harga jual dan jumlah tercatat sebagian objek ijarah yang telah dijual diakui sebagai keuntungan/kerugian

Jurnal:

Dr. Kas/piutang $\quad x x x$

Dr. Akm penyusutan $\quad \mathrm{xxx}$ 
Volume 5, Nomor 2, Agustus 2017

Dr. Kerugian

XXX

$\begin{array}{ll}\text { Kr. Aset ijarah } & \text { xxx } \\ \text { Kr. Keuntungan } & \text { xxx }\end{array}$

Bagian objek ijarah yang tidak dibeli penyewa diakui sebagai aset lancar/aset tidak lancar sesuai dengan tujuan penggunaan aset tersebut.

Jurnal:

Dr. Aset lancar/tidak lancar $\quad \mathrm{xxx}$

Dr. Akm penyusutan $\quad$ xxx

Kr. Aset ijarah

$\operatorname{XXX}$

\section{Akuntansi Penyewa (Musta'jir)}

a. Beban

Beban sewa diakui selama masa akad pada saat manfaat atas aset telah diterima

Jurnal:

Dr. Beban sewa xxx

\section{Kr. Kas/utang}

$\mathrm{xxx}$

Untuk pengakuan sewa di ukur sebesar jumlah yang harus dibayar atas manfaat yang telah diterima.

Biaya pemeliharaan objek ijarah yang disepakati dalam akad menjadi tanggungan penyewa diakui sebagai beban pada saat terjadinya. Sedangkan dalam ijarah muntahiyya bittamlik melalui penjualan objek ijarah yang menjadi beban penyewa akan meningkat sejalan dengan peningkatan kepemilikan objek ijarah.

Jurnal:

Dr. Beban pemeliharaan ijarah $\quad$ xxx

Kr. Kas/utang/perlangkapan $\quad$ xxx

Jurnal pencatatan atas biaya pemeliharaan yang menjadi tanggungan pemberi sewa tapi dibayarkan dahulu oleh penyewa

Jurnal:

Dr. Piutang $\operatorname{xxx}$

Kr. Kas/utang/perlengkapan

XXX

b. Perpindahan kepemilikan

i. Hibah, maka penyewa mengakui aset dan keuntungan sebesar nilai wajar objek ijarah yang diterima

Jurnal:

Dr. Aset nonkas

$\operatorname{xxx}$

Kr. Keuntungan

$\mathrm{xxx}$

ii. Pembelian sebelum masa akad berakhir, maka penyewa mengakui aset sebesar pembayaran sisa cicilan sewa atas jumlah yang disepakati
Jurnal:

Dr. Aset nonkas $\quad$ Xxx

Kr. Kas $\quad$ Xxx

iii. Pembelian setelah masa akad berakhir maka penyewa mengakui aset sebesar pembayaran yang disepakati

Dr. Aset nonkas

$\operatorname{XXX}$

Kr. Kas $\quad$ xxx

iv. Pembelian objek ijarah secara bertahap, maka penyewa mengakui aset sebesar pembayaran objek ijarah yang diterima (nilai wajar)

Dr. Aset nonkas $\quad \mathrm{xxx}$

Dr. Kas $\quad \mathrm{xxx}$

Kr. Utang $\quad$ Xxx

c. Jual-dan-Ijarah

Jika suatu entitas menjual objek ijarah kepada pihak lain dan kemudian menyewanya kembali, maka entitas tersebut mengakui keuntungan atau kerugian pada periode terjadinya penjualan dalam laporan laba rugi dan menerapkan perlakuan akuntansi penyewa.

d. Ijarah-Lanjut

Jika suatu entitas menyewakan lebih lanjut kepada pihak lain atas aset yang sebelumnya disewa dari pemilik, maka entitas tersebut menerapkan perlakuan akuntansi pemilik dan akuntansi penyewa dalam pernyataan ini.

\section{Penyajian, Pengungkapan, Ketentuan Transisi, Tanggal Efektif, dan Penarikan}

Menurut Ikatan Akuntan Indonesia (2009) penyajian, pengungkapan, ketentuan transisi, tanggal efektif, dan penarikan dapat dijelaskan sebagai berikut:

1. Penyajian

Berdasarkan PSAK No 107 pendapatan ijarah disajikan secara neto setelah dikurangi beban yang terkait, misalnya beban penyusutan, beban pemeliharaan dan perbaikan, dan sebagainya.

2. Pengungkapan

Berdasarkan PSAK No 107 pemilik mengungkapkan dalam laporan keuangan terkait transaksi ijarah dan ijarah muntahiyah bittamlik, tetapi tidak terbatas, pada:

- Penjelasan umum isi akad yang signifikan yangmeliputi tetapi tidak terbatas pada :i) 
keberadaan wa'ad pengalihan kepemilikan dan mekanisme yang digunakan (jika ada wa'ad pengalihan kepemilikan); ii) pembatasan pembatasan, misalnya ijarahlanjut; iii) agunan yang digunakan (jika ada);

- Nilai perolehan dan akumulasi penyusutan atau amortisasi untuk setiap kelompok aset ijarah;

- Keberadaan transaksi jual-dan-ijarah (jika ada).

Berdasarkan PSAK No 107, penyewa mengungkapkan dalam laporan keuangan terkait transaksi ijarahdan ijarah muntahiyahbittamlik, tetapi tidak terbatas, pada:

- Penjelasan umum isi akad yang signifikan yangmeliputi tetapi tidak terbatas pada:i) total pembayaran;ii) keberadaan wa'adpemilik untuk pengalihankepemilikan dan mekanisme yang digunakan(jika ada wa'adpemilik untuk pengalihankepemilikan);iii) pembatasanpembatasan, misalnya ijarah-lanjut;iv) agunan yang digunakan (jika ada);

- Keberadaan transaksi jual-dan-ijarahdan keuntunganatau kerugian yang diakui (jika ada transaksi jual-dan-ijarah).

3. Ketentuan Transisi

Pernyataan ini diterapkan secara prospektif.Penerapan secara retrospektif diperkenankan, tetapi tidakdisyaratkan.

4. Tanggal Efektif

Pernyataan ini berlaku untuk penyusunan danpenyajian laporan keuangan entitas yang dimulai padaatau setelah tanggal 1 Januari 2010.Penerapanlebih dinidianjurkan.Jika entitas menerapkan Pernyataan ini untukperiode yang dimulai sebelum 1 Januari 2010, maka faktatersebut harus diungkapkan.

5. Penarikan

Pernyataan ini menggantikan PSAK 59: AkuntansiPerbankan Syariah yang berhubungan dengan perlakuanakuntansi untuk pengakuan, pengukuran, penyajian danpengungkapan atas transaksi ijarah.

\section{Penelitian Sebelumnya}

Beberapa penelitian sebelumnya yang pernah dilakukan yang berkaitan dengan penelitian ini antara lain:

1. Martha Tona (2012)

Akuntansi akad ijarah muntahiyya bittamlik perspektif metode maqashid al-syariah. Metode penelitian menggunakan metode penelitian kualitatif dengan paradigma penelitian posypositivisme. Dengan paradigma ini peneliti melakukan penyimpulan secara deduktif dan logis dengan memberikan perhatian pada pengumpulan data empiris dan berdasarkan pada teori yang ada. Hasil penelitian ini mengkaji bagaimana penilaian teori maqashid al syariah terhadap pengakuan aset menurut akuntansi sewa guna usaha dengan opsi dan akuntansi ijarah muntahiyya bittamlik.

2. Rizkita Effendi (2013)

Analisis penerapan PSAK 107 tentang akuntansi ijarah dalam pembiayaan perbankan syariah. Metode penelitian yang digunakan metode kualitatif deskriptif. Hasil penelitian menunjukkan bahwa akuntansi ijarah pada pembiayaan perbankan syariah telah sesuai dengan PSAK No 107 tahun 2009

3. Arista Insaning Azizah (2014)

Analisis penerapan produk pembiayaan ijarah multijasa pada PT BPR Syariah Asri Madani Nusantara. Penelitian ini menggunakan metode kualitatif deskriptif. Hasil penelitian menyatakan bahwa perlakuan akuntansi pmbiayaan multijasa hanya mengacu pada PSAK 107 dan telah sesuai denganketetapannya. 


\section{Kerangka Konseptual}

Salah satu pembiayaan bank syariah yaitu ijarah dan ijarah muntahiyya bittamlik. Ijarah adalah akad pemindahan hak guna (manfaat) atas suatu aset dalam waktu tertentu dengan pembayaran sewa (ujrah) tanpa diikuti dengan pemindahan kepemilikan aset itu sendiri. Sedangkan ijarah muntahiyya bittamlik adalah akad sewa menyewa antara pemilik obyek sewa dan penyewa untuk mendapatkan imbalan atas obyek yang disewakannnya dengan opsi perpindahan hak milik obyek sewa pada saat tertentu sesuai dengan kesepakatan di awal akad.

Sewa yang dimaksud adalah sewa operasi (operating lease). Konsekuensinya, suatu ijarah didasarkan pada perjanjian antara orang yang menyewakan dan penyewa atas penggunaan aset tertentu. Orang yang menyewakan tetap sebagai pemilik aset dan penyewa menguasai serta menggunakan aset tersebut dengan membayar uang sewa tertentu untuk suatu periode waktu tertentu. Dalam prosesnya, pengakuan, pengukuran, pengungkapan dan penyajiannya haruslah sesuai dengan Standar Akuntansi Keuangan yang berlaku umum yaitu PSAK 107agar laporan keuangan yang dihasilkan lebih relevan.

Maka Kerangka konseptual dalam penelitian ini adalah sebagai berikut:

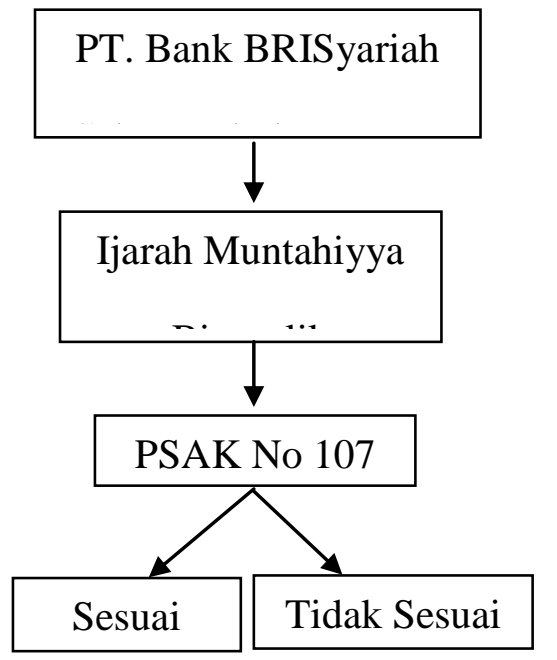

Gambar 1 Kerangka Konseptual

\section{METODOLOGI PENELITIAN}

\section{Lokasi dan Objek Penelitian}

Dalam penelitian ini peneliti memilih PT Bank Rakyat Indonesia Syariah Cabang Lhokseumawe yang berlokasi di Jl Merdeka Gp. Simpang Empat No. 39-40 Kecamatan Banda Sakti
Kota Lhokseumawe. Objek penelitian hanya mencakup pembiayaan ijarah yang dilakukan oleh PT Bank Rakyat Indonesia Syariah Cabang Lhokseumawe.

\section{Teknik Pengumpulan Data}

Teknik pengumpulan data pada penelitian ini adalah menggunakan metode wawancara. Data yang digunakan dalam penelitian ini diperoleh dari hasil wawancara dengan informan pada PT Bank BRISyariah Cabang Lhokseumawe, yang berhubungan dengan akad pembiayaan ijarah kemudian dideskriptifkan secara menyeluruh. Oleh karena itu, peneliti menggunakan data kualitatif untuk mengembangkan penelitian ini. Data kualitatif merupakan data yang berbentuk katakata, bukan dalam bentuk angka yang berasal dari PT Bank BRISyariah Cabang Lhokseumawe, yakni data yang diperoleh langsung dari informan yang bersangkutan.

\section{HASIL PENELITIAN DAN PEMBAHASAN}

Sistem Pembiayaan Ijarah Muntahiyya Bittamlik Pada PT Bank Rakyat Indonesia Syariah Cabang Lhokseumawe

Sistem pembiayaan ijarah muntahiyya bittamlik Pada PT Bank Rakyat Indonesia Syariah Cabang Lhokseumawe yaitu sistem perpindahan aset kepemilikan pada saat objek ijarah telah berakhir. Perpindahan aset dapat dilakukan dengan cara pemberian (hibah) kepada nasabah dan dengan cara menjual kepada nasabah sesuai dengan kesepakatan di awal akad. Pada saat perpindahan kepemilikan obyek ijarah dari pemilik kepada penyewa dalam ijarah muntahiyya bittamlik dengan cara pemberian (hibah) maka jumlah tercatat objek ijarah diakui sebagai beban. Sedangkan penjualan setelah selesai masa akad, maka selisih antara harga jual dan jumlah tercatat objek ijarah diakui sebagai keuntungan atau kerugian.

Analisis Kesesuaian Penerapan PSAK Nomor 107 Pembiayaan Ijarah Muntahiyya Bittamlik Pada PT Bank Rakyat Indonesia Syariah Cabang Lhokseumawe

Untuk melakukan analisis dan pembahasan dalam penelitian ini, peneliti menggunakan simulasi atas salah satu jenis pembiayaan yang menggunakan akad ijarah muntahiyya bittamlik. Ilustrasi yang digunakan mengenai pencatatan akuntansi pembiayaan ijarah muntahiyya bittamlik 
yang dilakukan oleh PT Bank BRISyariah, sehingga dapat diketahui pedoman standar akuntansi dan metode pengukuran yang digunakan oleh PT Bank BRISyariah dalam transaksi pembiayaan ijarah muntahiyya bittamlik.

Berikut ini adalah contoh simulasi pembiayaan IMBT :

Pembiayaan ini menggunakan skema ijarah muntahiyya bittamlik dengan pola pembayaran angsuran pokok setiap bulan. Informasi pembiayaan adalah sebagai berikut:

- Besarnya biaya perolehan objek

Rp 120.000.000.-

- Jangka waktu

2 tahun ( 24 bulan)

- Tujuan

sewa satu unit rumah

- Pencairan

1 Januari 2015

- Periode angsuran februari 2015 s/d januari 2017

- Angsuran pelunasan bulan 1 s/d 122016 sebesar Rp 60.000.000.bulan $1 \mathrm{~s} / \mathrm{d} 122017$ sebesar $\mathrm{Rp} 60.000 .000-$ maka total angsuran sebesar Rp 120.000.000.

- Kebijakan keuntungan pemilik $20 \%$ dari modal obyek sewa

- Pelaksanaan pembayaran angsuran dilakukan oleh nasabah setiap tanggal 30

- Perhitungan penyusutan aset IMBT

Berdasarkan PSAK objek sewa disusutkan sesuai dengan masa sewa jika merupakan transaksi ijarah muntahiyya bittamlik

Berdasarkan kasus diatas maka beban penyusutan perbulan objek IMBT adalah:

Penyusutan IMBT per bulan = biaya perolehan Jumlah bulan masa sewa

Penyusutan IMBT per bulan $=\underline{R p ~ 120.000 .000,-}$

$$
24
$$

$$
=\operatorname{Rp} 5.000 .000,-
$$

- Jadwal pembayaran angsuran pokok dapat dilihat pada tabel 2 sebagai berikut:

Tabel 2 Jadwal Pembayaran Angsuran Sewa

\begin{tabular}{|c|c|c|}
\hline 3 & $30 / 04 / 2015$ & Rp 5.000.000 \\
\hline 4 & $30 / 05 / 2015$ & Rp 5.000.000 \\
\hline 5 & $30 / 06 / 2015$ & Rp 5.000.000 \\
\hline 6 & $30 / 07 / 2015$ & Rp 5.000.000 \\
\hline 7 & $30 / 08 / 2015$ & Rp 5.000.000 \\
\hline 8 & $30 / 09 / 2015$ & Rp 5.000.000 \\
\hline 9 & $30 / 10 / 2015$ & Rp 5.000.000 \\
\hline 10 & $30 / 11 / 2015$ & Rp 5.000.000 \\
\hline 11 & $30 / 12 / 2015$ & Rp 5.000.000 \\
\hline 12 & $30 / 01 / 2016$ & Rp 5.000.000 \\
\hline 13 & $30 / 02 / 2016$ & Rp 5.000.000 \\
\hline 14 & $30 / 03 / 2016$ & Rp 5.000.000 \\
\hline 15 & $30 / 04 / 2016$ & Rp 5.000.000 \\
\hline 16 & $30 / 05 / 2016$ & Rp 5.000.000 \\
\hline 17 & $30 / 06 / 2016$ & Rp 5.000.000 \\
\hline 18 & $30 / 07 / 2016$ & Rp 5.000.000 \\
\hline 19 & $30 / 08 / 2016$ & Rp 5.000.000 \\
\hline 20 & $30 / 09 / 2016$ & Rp 5.000.000 \\
\hline 21 & $30 / 10 / 2016$ & Rp 5.000.000 \\
\hline 22 & $30 / 11 / 2016$ & Rp 5.000.000 \\
\hline 23 & $30 / 12 / 2016$ & Rp 5.000.000 \\
\hline \multirow[t]{2}{*}{24} & $30 / 01 / 2017$ & Rp 5.000.000 \\
\hline & Total & $\begin{array}{c}\text { Rp } \\
120.000 .000 .\end{array}$ \\
\hline
\end{tabular}

\begin{tabular}{|c|c|c|}
\hline Skedul & $\begin{array}{c}\text { Tanggal } \\
\text { pembayaran }\end{array}$ & Angsuran sewa \\
\hline 1 & $30 / 02 / 2015$ & Rp 5.000 .000 \\
\hline 2 & $30 / 03 / 2015$ & Rp 5.000 .000 \\
\hline
\end{tabular}

Selanjutnya dengan kebijakan keuntungan sewa $20 \%$ dari modal barang yang disewakan, pendapatan IMBT per bulan adalah sebagai berikut: 
Pendapatan IMBT per bulan

$=$ modal penyewaan $+\mathrm{n} \%$ modal penyewaan

$=\operatorname{Rp} 5.000 .000+(20 \% \times 5.000 .000)$

$=\operatorname{Rp} 5.000 .000+1.000 .000$

$=\operatorname{Rp} 6.000 .000$

Maka Total pendapatan IMBT selama masa sewa adalah:

$=24 \times \operatorname{Rp} 6.000 .000$

$=\operatorname{Rp} 144.000 .000$

Jadi, keuntungan sewa yang didapatkan oleh bank selama 2 tahun adalah

$=$ Total pendapatan IMBT selama sewa - Biaya Perolehan Objek sewa

$=\operatorname{Rp} 144.000 .000-\operatorname{Rp} 120.000 .000$

$=\operatorname{Rp} 24.000 .000 .-$

\section{Perlakuan Pencatatan Akuntansi}

\section{Pengakuan dan Pengukuran}

\section{Akuntansi Pemilik (Mu'jir)}

a. Biaya perolehan

Pencatatan menurut PSAK No. 107:

Dr. Aset ijarah $\quad \mathrm{xxx}$

$$
\text { Kr. Kas/Utang } \quad \text { Xxx }
$$

Pencatatan menurut BRISyariah:

Dr. Aktiva ijarah $\quad \mathrm{xxx}$

Cr. Kas/Rekening Supplier

$\mathrm{XXX}$

Hasil analisis:

- Biaya yang dikeluarkan oleh BRISyariah akibat akad ijarah diakui sebesar biaya perolehan objek

- Biaya perolehan objek ijarah dapat berupa aset tetap dan aset tidak berwujud

Pencatatan ini telah sesuai dengan PSAK Nomor107 par 09. b. Penyusutan dan Amortisasi

Pencatatan menurut PSAK Nomor 107:

Dr. Biaya Penyusutan $\quad$ xxx

Kr. Akm penyusutan $\quad$ Xxx

Pencatatan menurut BRISyariah:

Dr. P/L Beban penyusutan Aktiva Ijarah xxx

Cr. Akumulasi Penyusutan Aktiva Ijarah $\quad$ xxx

Hasil analisis:

- Biaya yang dikeluarkan oleh BRISyariah jika terjadinya penyusutan aset dan amortisasi dicatat sebagai beban penyusutan aset ijarah

- Penyusutan obyek ijarah dapat berupa aset tetap dan aset tidak berwujud.

Pencatatan yang dilakukan telah sesuai dengan PSAK Nomor 107 par 11.

c. Pendapatan dan beban

Pencatatan menurut PSAK Nomor 107:

Dr. Kas/Piutang Usaha Xxx

Kr. Pendapatan Sewa

$\mathrm{XXX}$

Pencatatan menurut BRISyariah:

Dr. Piutang Ijarah Xxx

Cr. Pendapatan Ujroh

XXX

Hasil analisis:

Pada Bank BRISyariah piutang pendapatan sewa diukur pada saat pengakuan pendapatan ijarah pada akhir bulan

Pencatatan yang dilakukan telah sesuai dengan PSAK 107 par 15.

d. Perpindahan kepemilikan

Pada saat perpindahan kepemilikan obyek ijarah dari pemilik kepada penyewa dalam ijarah muntahiyya bittamlik dengan cara:

Hibah, maka jumlah tercatat objek ijarah diakui sebagai beban

Dr. Beban ijarah $\quad$ xxx

Dr. Akm penyusutan $\mathrm{xxx}$

$\mathrm{Kr}$. Aset ijarah $\mathrm{xxx}$

Penjualan setelah selesai masa akad, maka selisih antara harga jual dan jumlah tercatat objek ijarah diakui sebagai keuntungan atau kerugian

Dr. Kas/piutang $\quad$ xxx

Dr. Akm penyusutan $\quad \mathrm{xxx}$ 


\author{
Dr. Kerugian \\ Kr. Aset ijarah \\ $\operatorname{xxx}$ \\ Kr. Keuntungan \\ $\operatorname{xxx}$ \\ $\mathrm{xxx}$
}

\section{Penyajian}

Penyajian Menurut PSAK 107:

Pendapatan ijarah disajikan secara netto setelah dikurangi beban yang terkait, misalnya beban penyusutan, beban pemeliharaan dan perbaikan, dan sebagainya.

Penyajian Menurut BRISyariah:

Akun-akun yang berkaitan dengan pembiayaan ijarah dan IMBT disajikan di neraca dan laporan laba rugi. Pada neraca, di sisi aktiva tidak lancar, terdapat akun aset yang diperoleh untuk ijarah yang menunjukkan nilai perolehan aset yang disewakan kepada nasabah. Kemudian terdapat akun akumulasi penyusutan yang nilainya menjadi pengurang atas akun aset yang diperoleh untuk ijarah. Pada laporan laba rugi, terdapat pendapatan ijarah secara netto yang merupakan hasil dari total pendapatan ijarah dan IMBT dikurangi dengan beban penyusutan aset aset yang menjadi obyek ijarah.

Hasil analisis:

Penyajian laporan keuangan pada PT Bank BRISyariah telah sesuai dengan PSAK 107.

\section{Pengungkapan}

Pengungkapan menurut PSAK 107:

Pemilik mengungkapkan dalam laporan keuangan terkait transaksi ijarah dan ijarah muntahiyya bittamlik, tetapi tidak terbatas pada:

a. Penjelasan umum isi akad yang signifikan yang meliputi tetapi tidak terbatas pada:

(i) Keberadaan wa'ad pengalihan kepemilikan dan mekanisme yang digunakan ( jika ada wa'ad pengalihan kepemilikan)

(ii) Pembatasan-pembatasan, misalnya ijarah lanjut

(iii) Agunan yang digunakan (jika ada)

b. Nilai perolehan dan akumulasi penyusutan atau amortisasi untuk setiap kelompok ijarah

c. Keberadaan transaksi jual-dan-ijarah (jika ada) Penyewa mengungkapkan dalam laporan keuangan terkait transaksi ijarah dan ijarah muntahiyya bittamlik, tetapi tidak terbatas pada: a. Penjelasan umum isi akad yang signifikan yang meliputi tetapi tidak terbatas pada:

(i) Total pembayaran

(ii) Keberadaan wa'ad pemilik untuk pengalihan kepemilikan dan mekanisme yang digunakan (jika ada wa'ad pemilik untuk pengalihan kepemilikan)

(iii) Pembatasan-pembatasan, misalnya ijarahlanjut

(iv) Agunan yang digunakan (jika ada)

b. Keberadaan transaksi jual-dan-ijarah dan keuntungan atau kerugian yang diakui (jika ada transaksi jual-dan-ijarah)

Pengungkapan menurut BRISyariah:

BRISyariah mengungkapkan apa yang dimaksud dengan aset yang diperoleh untuk ijarah serta mengklasifikasikan biaya perolehan pertahun buku untuk masing-masing jenis aset ijarah, kemudian BRISyariah juga menginformasikan nilai penambahan dan pengurangan aset ijarah. Selanjutnya, pendapatan ijarah maupun IMBT tergabung pada satu akun pendapatan ijarah dan ijarah muntahiyya bittamlik. Akun ini menunjukkan besar pendapatan sewa yang diterima oleh BRISyariah.

Hasil analisis:

Pengungkapan pada laporan keuangan yang dilakukan oleh BRISyariah telah sesuai dengan PSAK 107.

\section{PENUTUP}

\section{Kesimpulan}

Salah satu pembiayaan syariah yang terdapat pada PT Bank Rakyat Indonesia Syariah Cabang Lhokseumawe yaitu pembiayaan ijarah. Adapunijarah yang di aplikasikan pada PT Bank Rakyat Indonesia Syariah Cabang Lhokseumawe yaitu ijarah muntahiyya bittamlik. Ijarah muntahiyya bittamlik yaitu akad sewa menyewa yang dilakukan oleh kedua pihak yang berakad atas suatu aset tertentu dengan pembayaran sewa (ujrah) dengan wa'd perpindahan kepemilikan aset yang di ijarah kan pada saat tertentu.

Sistem pembiayaan ijarah muntahiyya bittamlik Pada PT Bank Rakyat Indonesia Syariah Cabang Lhokseumawe yaitu sistem perpindahan aset kepemilikan pada saat objek ijarah telah berakhir. Perpindahan aset dapat dilakukan dengan cara pemberian (hibah) kepada nasabah dan dengan 
cara menjual kepada nasabah sesuai dengan kesepakatan di awal akad. Pada saat perpindahan kepemilikan obyek ijarah dari pemilik kepada penyewa dalam ijarah muntahiyya bittamlik dengan cara pemberian (hibah) maka jumlah tercatat objek ijarah diakui sebagai beban. Sedangkan penjualan setelah selesai masa akad, maka selisih antara harga jual dan jumlah tercatat objek ijarah diakui sebagai keuntungan atau kerugian.

Perlakuan pencatatan akuntansi ijarah muntahiyya bittamlik yaitu:

$\checkmark$ Akuntansi Pemilik(mu'jir)

- Biaya perolehan: Biaya yang dikeluarkan oleh BRISyariah akibat akad ijarah diakui sebesar biaya perolehan objek dan biaya perolehan objek ijarah dapat berupa aset tetap dan aset tidak berwujud. Pencatatan ini telah sesuai dengan PSAK Nomor 107 par 09.

- Penyusutan dan amortisasi:Biaya yang dikeluarkan oleh BRISyariah jika terjadinya penyusutan aset dan amortisasi dicatat sebagai beban penyusutan aset ijarahdanpenyusutan obyek ijarah dapat berupa aset tetap dan aset tidak berwujud. Pencatatan yang dilakukan telah sesuai dengan PSAK Nomor 107 par 11.

- Pendapatan dan beban: Pada Bank BRISyariah piutang pendapatan sewa diukur pada saat pengakuan pendapatan ijarah pada akhir bulan. Pencatatan yang dilakukan telah sesuai dengan PSAK 107 par 15.

- Perpindahan kepemilikan: Pada saat perpindahan kepemilikan objek ijarah dari pemilik kepada penyewa dalam ijarah muntahiyya bittamlik dengan cara: Hibah, maka jumlah tercatat objek ijarah diakui sebagai beban. Penjualan sebelum berakhirnya masa, sebesar sisa cicilan sewa atau jumlah yang disepakati maka selisih antara harga jual dan jumlah yang tercatat sebagai objek ijarah dapat diakui sebagai keuntungan/kerugian. Penjualan setelah selesai masa akad, maka selisih antara harga jual dan jumlah tercatat objek ijarah diakui sebagai keuntungan atau kerugian. Penjualan objek ijarah secara bertahap, maka selisih harga jual dan jumlah tercatat sebagian objek ijarah yang telah dijual diakui sebagai keuntungan/kerugian Bagian objek ijarah yang tidak dibeli penyewa diakui sebagai aset lancar/aset tidak lancar sesuai dengan tujuan penggunaan aset tersebut. Pencatatan yang dilakukan telah sesuai dengan PSAK nomor 107 par 19.

$\checkmark$ Penyajian: Akun-akun yang berkaitan dengan pembiayaan ijarah dan IMBT disajikan di neraca dan laporan laba rugi. Pada neraca, di sisi aktiva tidak lancar, terdapat akun aset yang diperoleh untuk ijarah yang menunjukkan nilai perolehan aset yang disewakan kepada nasabah. Kemudian terdapat akun akumulasi penyusutan yang nilainya menjadi pengurang atas akun aset yang diperoleh untuk ijarah. Pada laporan laba rugi, terdapat pendapatan ijarah secara netto yang merupakan hasil dari total pendapatan ijarah dan IMBT dikurangi dengan beban penyusutan aset aset yang menjadi obyek ijarah.

$\checkmark$ Pengungkapan: BRISyariah mengungkapkan apa yang dimaksud dengan aset yang diperoleh untuk ijarah serta mengklasifikasikan biaya perolehan pertahun buku untuk masing-masing jenis aset ijarah, kemudian BRISyariah juga menginformasikan nilai penambahan dan pengurangan aset ijarah. Selanjutnya, pendapatan ijarah maupun IMBT tergabung pada satu akun pendapatan ijarah dan ijarah muntahiyya bittamlik. Akun ini menunjukkan besar pendapatan sewa yang diterima oleh BRISyariah.

Dari uraian diatas penulis mengambil kesimpulan bahwa perlakuan akuntansi ijarah pada PT Bank Rakyat Indonesia Syariah Cabang Lhokseumawe telah sesuai dengan prinsip akuntansi yang berlaku umum untuk perbankan syariah yaitu PSAK Nomor 107 tentang penerapan akuntansi pembiayaan ijarah.

\section{Saran}

1. PT Bank Rakyat Indonesia Syariah Cabang Lhokseumawe diharapkan dapat bertahan pada situasi perbankan saat ini di mana persaingan antara bank semakin kuat.

2. Bagi peneliti selanjutnya diharapkan agar dapat melakukan penelitian tentang pencatatan transaksi praktik ijarahmuntahiyya bittamlik pada bank atau lembaga keuangan lainnya sehingga dapat memberikan gambaran yang lebih beragam tentang pembiayaan ijarah muntahiyya bittamlik. 


\section{DAFTAR PUSTAKA}

Antonio, Muhammad Syafi'i. (2006). Dasar-Dasar Manajemen Bank Syariah. Cetakan Keempat Pustaka Alfabeta. Jakarta.

Antonio, Muhammad Syafi'i. (2005). Bank Syariah dan Teori ke Praktek, Cetakan Ketiga Gema Insani Press. Jakarta.

Ascarya. (2011). Akad \& Produk Bank Syariah. Jakarta: PT. Raja Grafindo Persada.

Arista Insaning Azizah. (2014). Analisis Penerapan Akuntansi Produk Pembiayaan Ijarah Multijasa Pada PT BPR Syariah Asri Madani Nusantara. Jurnal Ekonomi dan Bisnis.

Biro Perbankan Syariah. (2004). Pedoman Akuntansi Perbankan Syariah Indonesia. Jakarta.

Departemen Agama Republik Indonesia. (1992). Alqur'an dan Terjemahannya. CV Toha Putra. Semarang.

Dicky Rusandi. (2014). Penerapan Akuntansi Pembiayaan Ijarah pada PT Bank Muamalat Indonesia Kantor Cabang Jember. Jurnal Ekonomi dan Bisnis.

Dian Gunawan. (2013). Penerapan PSAK 107 atas Transaksi Ijarah Pada PT BNI Syariah Cabang Makassar. Skripsi Sarjana Diterbitkan. Universitas Hasanuddin.

Fatwa Dewan Syariah Nasional NO: 09/DSNMUI/IV/2000. Tentang Pembiayaan Ijarah.

Hidayat Rahmat. (2014).Efesiensi Perbankan Syariah : Teori Dan Praktek Gramata Publishing, Jawa Barat.

Ikatan Akuntan Indonesia.(2011). Pernyataan Standar Akuntansi Keuangan No. 107 tentang Ijarah. Salemba Empat. Jakarta.

Khaddafi Muammar, dkk. (2016). Akuntansi Syariah Meletakkan Nilai-Nilai Syariah Islam Dalam Ilmu Akuntansi : Madenatera, Medan.
Muhammad. (2005). Pengantar Akuntansi Syariah, Edisi Kedua, Salemba Empat. Jakarta.

Muhammad Faris. (2017). Analisis Faktor-faktor Yang Mempengaruhi Pembiayaan IMBT Bank Pembiayaan Rakyat Syariah di Indonesia. Skripsi Sarjana Diterbitkan. Institut Pertanian Bogor.

Martha Tona. (2012). Akuntansi Akad Ijarah Muntahiyya Bittamlik Persepektif Metode Maqashid Al-Syaria. Jurnal Ekonomi dan Bisnis.

Maryana Latifa. (2013). Analisis Perbandingan PSAK 107 dan Fatwa MUI Terhadap Praktik Transaksi Ijarah KMBT Tadbiratul Ummah. Jurnal Ekonomi dan Bisnis.

Nurhayati, Sri danWasilah. (2009). Akuntansi Syariah di Indonesia Edisi 2. Salemba Empat. Jakarta.

Saiful. (2009). Memahami Penlitian Kualitatif. Alfabeta, Bandung.

Sjahdeini Sutan Remy. (2007). Perbankan Islam. Jakarta : PT Pustaka Utama Grafiti, Cetakan Ketiga.

Silviana Aprilia, Muhammad Yusuf. (2011). Analisis Penerapan Akuntansi Ijarah pada PT Bank DKI Cabang Syariah Wahid Hasyim. Jurnal Ekonomi dan Bisnis.

Sudarsono, Edi. (2007). Bank dan Lembaga Keuangan Syari'ah. Yogyakarta : EKONISIA.

Taufiqi, Ahmad. (2011). Metodologi Penelitian Praktis. Yogyakarta : Teras.

Wiyono, Slamet, (2005). Cara Mudah Memahami Akuntansi Syariah Berdasarkan PSAK dan PAPSI. Penerbit PT> Gramedia Widiasarana Indonesia, Jakarta.

Yusuf, Muhammad. (2012). Analisis Penerapan Akuntansi Musyarakah Terhadap PSAK 106 pada Bank Syariah X. Skripsi Sarjana Diterbitkan. Binus University. 